\title{
Nuclear and Satellite DNA Base Composition and the Taxonomy of Saprolegnia (Oomycetes)
}

\author{
By G. A. NEISH AND BEVERLEY R. GREEN \\ Department of Botany, University of British Columbia, Vancouver, \\ British Columbia, Canada V6T I W5
}

(Received I2 January 1976; revised 22 March 1976)

\section{INTRODUCTION}

The genus Saprolegniasensustricto(Dick, 1973) contains I 2 'morphospecies' (see Scudder, 1974) separated from each other primarily on the basis of five key characters (Seymour, 1970): (i) presence or absence of antheridia; (ii) antheridial origin; (iii) presence or absence of pitting on the oogonial wall; (iv) presence of centric or subcentric oospores; and (v) oospore diameter.

The weight given to each of these characters varies for the different species and this has resulted in both broadly (e.g. S. ferax) and narrowly (e.g. S. hypogyna) defined species which may be separated from one another by differences in only one character. Furthermore, some important characters are culturally variable, some isolates apparently lose the ability to form oogonia in culture, and still other isolates have never been induced to form oogonia and therefore cannot be assigned to any species using the presently accepted criteria.

There are several problems associated with the accumulation of cytogenetic information for the genus so the extent to which morphological variations indicate genetic relationships is unknown (Dick, 1972; Dick \& Win-Tin, 1973), but work by Storck \& Alexopoulos (1970), Green \& Dick (1972) and Clark-Walker \& Gleason (1973) suggests that Saprolegnia species may have DNA base compositions that are sufficiently divergent to make this a useful character for separating isolates at the infrageneric level. In addition, the isolates examined by Green \& Dick (1972) and Clark-Walker \& Gleason (1973) contain a satellite DNA which might also be a useful taxonomic indicator.

\section{METHODS}

Isolates. We used II isolates of Saprolegnia (Table I) assigned to the following species: $S$. diclina Humphrey, S. hypogyna (Pringsheim) de Bary, S. parasitica Coker, and S. ferax (Gruithuisen) Thuret, the type species. For the purposes of this communication we have not distinguished between $S$. diclina and $S$. parasitica and refer isolates assigned to these species to the $S$. diclina-S. parasitica complex. Two of the isolates (IBH and ATCC22284) had apparently lost the ability to produce oogonia in culture so their identities could not be confirmed: these have been retained in the species to which they were assigned by the investigators who originally isolated them.

To help rule out the possibility that the satellite DNA band was of viral origin, two isolates (GANI7 and GANI8) were examined using methods similar to those described by Volkoff, Walters \& Dejardin (1972). Another species in the Saprolegniaceae, Aphanomyces astaci Schikora, may contain mycoplasma-like structures (Heath \& Unestam, 1974), so this possibility was tested by isolating DNA from isolate IBH which has been examined 
Table I. Identity of the Saprolegnia isolates used for this study and the CsCl buoyant density and \% GC of their DNA

\begin{tabular}{|c|c|c|c|c|c|c|}
\hline \multirow[b]{2}{*}{ Species } & \multirow[b]{2}{*}{ Source/no.* } & \multirow[b]{2}{*}{ Origin } & \multicolumn{2}{|c|}{$\begin{array}{l}\text { Buoyant density } \\
\qquad\left(\mathrm{g} \mathrm{cm}^{-3}\right) \dagger\end{array}$} & \multicolumn{2}{|c|}{$\% \mathrm{GC}$} \\
\hline & & & $\begin{array}{l}\text { Main } \\
\text { band }\end{array}$ & Satellite & $\begin{array}{l}\text { Main } \\
\text { band }\end{array}$ & Satellite \\
\hline $\begin{array}{l}S . \text { diclina-S. parasitica } \\
\text { complex }\end{array}$ & APCC2O4e & $\begin{array}{l}\text { Marion Lake, British } \\
\text { Columbia, Canada }\end{array}$ & $1 \cdot 718$ & $I \cdot 708$ & 59 & 49 \\
\hline $\begin{array}{l}\text { S. diclina-S. parasitica } \\
\text { complex }\end{array}$ & ATCC22284 & $\begin{array}{l}\text { Christiansburg, Virginia, } \\
\text { U.S.A., from } \\
\text { Ictalurus punctatus }\end{array}$ & $1 \cdot 717$ & $1 \cdot 707$ & 58 & 48 \\
\hline $\begin{array}{l}\text { S. diclina-S. parasitica } \\
\text { complex }\end{array}$ & $\operatorname{CBS} 282 \cdot 38$ & England & $I \cdot 718$ & $1 \cdot 708$ & 59 & 49 \\
\hline $\begin{array}{l}\text { S. diclina-S. parasticia } \\
\text { complex }\end{array}$ & GANI 7 & $\begin{array}{l}\text { Robertson Creek } \\
\text { Hatchery ( } 124^{\circ} 59^{\prime} \mathrm{W}, \\
\left.49^{\circ} 20^{\prime} \mathrm{N}\right) \text {, British } \\
\text { Columbia, Canada, from } \\
\text { Oncorhynchus nerka }\end{array}$ & $I \cdot 717$ & $\mathbf{I} \cdot 708$ & 58 & 49 \\
\hline Saprolegnia sp. & GAN24 & As GANI 7 & $1 \cdot 718$ & $\mathrm{I} \cdot 707$ & 59 & 48 \\
\hline Saprolegnia sp. & GANI 8 & As GANI 7 & $1 \cdot 717$ & $\mathrm{I} \cdot 707$ & 58 & 48 \\
\hline S. ferax & IBH & University of Leeds & $I \cdot 718$ & $1 \cdot 707$ & 59 & 48 \\
\hline S. ferax & APCC204a & Bedgebury, England & $1 \cdot 718$ & $I \cdot 707$ & 59 & 48 \\
\hline S. ferax & APCC204b & Lake District & $1 \cdot 718$ & $1 \cdot 708$ & 59 & 49 \\
\hline S. ferax & $\begin{array}{l}\text { ATCC26I I } 6 \\
(\mathrm{RE} 47-15 \mathrm{a})\end{array}$ & $\begin{array}{l}\text { University of California, } \\
\text { Berkeley, U.S.A. }\end{array}$ & $1 \cdot 718$ & I 708 & 59 & 49 \\
\hline S. hypogyna & APCC206a & S.E. England & $I \cdot 718$ & $1 \cdot 706$ & 59 & 47 \\
\hline
\end{tabular}

* Abbreviations: APCC, Aquatic Phycomycete Culture Collection, Department of Botany, University of Reading: all APCC cultures were sent by courtesy of Dr M. W. Dick; ATCC, American Type Culture Collection, Rockville, Maryland, U.S.A.; CBS, Centraalbureau voor Schimmelcultures, Baarn, The Netherlands; GAN, G. A. Neish, Department of Botany, University of British Columbia, Canada; IBH, Dr I. B. Heath, Department of Biology, York University, Downsview, Ontario, Canada: this isolate is also deposited in APCC as no. 204g; RE, Dr Ralph Emerson, Department of Botany, University of California, Berkeley, U.S.A.

$\dagger$ The values given are the mean of two separate determinations. The range of buoyant densities for the main band was $\mathrm{I} \cdot 7 \mathrm{I} 6$ to $\mathrm{I} \cdot 7 \mathrm{I} 8 \mathrm{~g} \mathrm{~cm}^{-3}$; for the satellite, $\mathrm{I} \cdot 706$ to $\mathrm{I} \cdot 709 \mathrm{~g} \mathrm{~cm}^{-3}$. Individual results were accurate to $\pm 0.001 \mathrm{~g} \mathrm{~cm}^{-3}$.

extensively by electron microscopy and in which no mycoplasma-like structures have ever been detected (I. B. Heath, personal communication).

The cultures were tested for the presence of bacterial contamination by growing them in tryptone-yeast extract broth (Neish, 1975a).

DNA isolation and buoyant density determination. The method used for isolating the DNA was adapted from those of Green \& Dick (1972) and Marmur (196I). The DNA buoyant density of one isolate (ATCC26II6) has been determined previously (Clarke-Walker \& Gleason, 1973) and was used to check our methods.

Mycelium, harvested by suction filtration, was washed with distilled water, frozen in liquid nitrogen, ground to a fine powder and suspended in diethyldithiocarbamate buffer (Green \& Dick, 1972). To the suspension was added an equal volume of liquified phenol/ suspension buffer $(9: \mathrm{I}, \mathrm{v} / \mathrm{v})$, and sodium dodecyl sulphate to a final concentration of $0.02 \mathrm{~g} \mathrm{ml}^{-1}$. This suspension was stirred for $30 \mathrm{~min}$, the phases were separated by centrifuging, and the aqueous phase was treated once with phenol and once with chloroform/isoamyl 
alcohol to remove protein. Cold $95 \%(\mathrm{v} / \mathrm{v})$ ethanol was then added to the aqueous supernatant to precipitate the nucleic acids. The precipitate was dissolved in standard saline citrate (SSC) buffer (Green \& Dick, 1972) and then incubated at $37^{\circ} \mathrm{C}$ with $\mathrm{T}_{1}$-ribonuclease, pancreatic ribonuclease and $\alpha$-amylase (Green \& Dick, 1972) followed by predigested pronase at $45^{\circ} \mathrm{C}$, and protein was again removed by treatment with chloroform/isoamyl alcohol. The DNA was precipitated with $95 \%$ ethanol, dissolved in $0.1 \times S S C$ and reprecipitated with isopropanol/acetate/EDTA(Marmur, I96I). This precipitate was collected by centrifuging, washed with ethanol, dissolved in SSC and stored frozen.

Ultraviolet absorption spectra $\left(E_{\max }, 257 \mathrm{~nm} ; E_{260} / E_{280}, \mathrm{I} \cdot 80\right.$ to I $\left.\cdot 96\right)$ and diphenylamine assays (Burton, 1968) were used to estimate the purity and concentration of the DNA preparations. DNA base compositions were determined from buoyant density measurements in caesium chloride (Schildkraut, Marmur \& Doty, 1962).

\section{RESULTS AND DISCUSSION}

The main DNA component of all the isolates (Fig. I; Table I) had a buoyant density of $\mathrm{I} \cdot 7 \mathrm{I} 7 \pm 0.001 \mathrm{~g} \mathrm{~cm}^{-3}(58 \pm \mathrm{I} \% \mathrm{GC})$ which is within the range of experimental error. These results agree well with those obtained by Green \& Dick (1972) for three isolates belonging to the $S$. diclina-S. parasitica complex, and by Clark-Walker \& Gleason (1973) for ATCC26I I6, recently identified as $S$. ferax (Neish, $1975 b$ ). Our results are also in reasonable agreement with those obtained by Storck \& Alexopoulos ( 1970 ) for S. hypogyna and S. parasitica (59, against their values of 55.5 and $60.5 \%$ GC respectively). However, their report of $49.5 \%$ GC for $S$. ferax is $9.5 \%$ lower than our value for four different isolates of that species and, in fact, coincides with the position of our satellite component. This could not be due to experimental error in determination of the base composition, since they used the same buoyant density method. Unfortunately, this problem must remain unresolved since the isolate in question is no longer extant (E. S. Beneke, personal communication).

With this exception, the variation of base composition in the genus Saprolegnia sensu stricto appears to be at least within $5 \% \mathrm{GC}(55.5$ to $60.5 \% \mathrm{GC})$ and may be within $3 \% \mathrm{GC}$ ( 57 to $59 \% \mathrm{GC}$ ). Clearly, analysis of DNA base composition cannot be used for separating species of Saprolegnia in accordance with classical morphological species concepts, but our data do suggest that Saprolegnia may be a relatively homogeneous taxon and that any isolate whose base composition is not between 55.5 and $60.5 \% \mathrm{GC}$ should be excluded from the genus. Further clarification of the infrageneric relationships of Saprolegnia species may have to be based on analysis of the DNA-DNA homologies between different isolates.

All isolates examined had a more or less well-defined satellite DNA with a buoyant density of $\mathrm{I} \cdot 706$ to $\mathrm{I} \cdot 709 \mathrm{~g} \mathrm{~cm}^{-3}$ ( 47 to $50 \% \mathrm{GC}$ ) (Fig. I ; Table I). This satellite DNA was also found in three isolates of the $S$. diclina-S. parasitica complex by Green \& Dick (I972), who showed that it was deoxyribonuclease sensitive and not due to contamination of cultures by bacteria or other fungi. The satellite was also reported by Clark-Walker \& Gleason (1973) in $S$. ferax (ATCC26II6). They showed that it was not mitochondrial DNA, which had a much lower buoyant density of $\mathrm{I} .685 \mathrm{~g} \mathrm{~cm}^{-3}$. We did not detect any virus-like particles in the two isolates GANI7 and GANI8, both of which have distinct satellite bands. A mycoplasmal origin is unlikely because isolate IBH has a wellseparated satellite peak, and no mycoplasma-like bodies have ever been detected in it. It is therefore most likely that this satellite DNA is of nuclear origin. Nuclear satellite DNA has been found in various eukaryotes (Walker, 197I ; Ingle, Pearson \& Sinclair, 1973) but has not been commonly reported for fungi (Storck, 1974). 

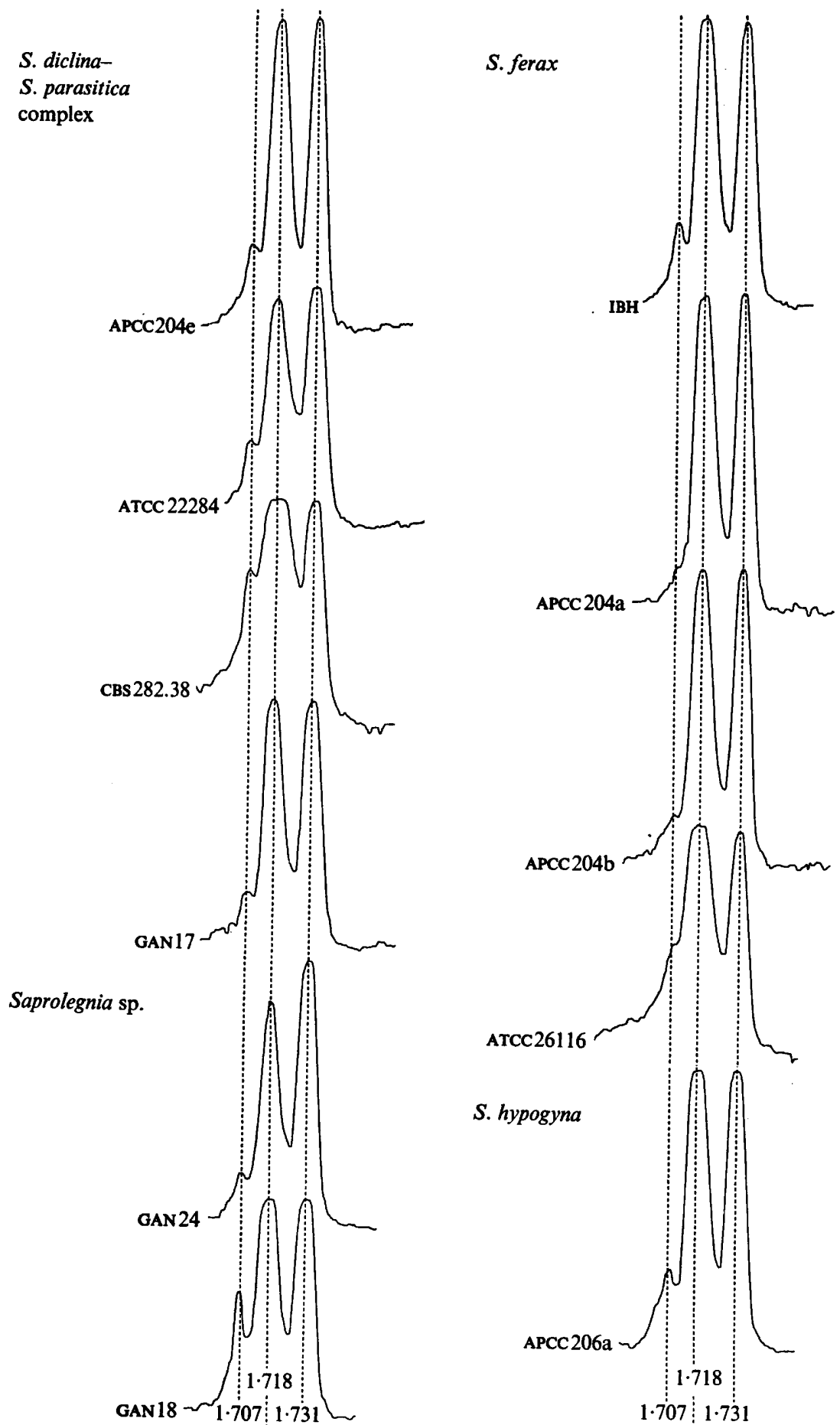

Fig. I. Microdensitometer tracings of the caesium chloride equilibrium gradients of the DNA of isolates of Saprolegnia. The numbers represent buoyant densities in $\mathrm{g} \mathrm{cm}^{-3}$. The peak on the right is reference DNA of Micrococcus lysodeikticus $\left(\rho=\mathrm{I} \cdot 73 \mathrm{I} \mathrm{g} \mathrm{cm}^{-3}\right)$. The lines in the figure approximate to the correct buoyant density; for precise values, see Table $\mathrm{I}$. 
The amount of satellite DNA in the Saprolegnia isolates varied from about $20 \%$ of the total DNA extracted (Fig. I, GANI8) to about $5 \%$ (Fig. I, APCC204b). As yet we have no explanation for this phenomenon. It may be an artefact, represent real differences in the genome (Gibson \& Hewitt, I972), or be related to the physiological state of the organism at the time of harvest. For example, if the satellite DNA were coding for ribosomal RNA, the variation in amount could represent.amplification of the rRNA genes (Ingle et al., I973). When the nature of the satellite component is better understood, it may prove to be of taxonomic value at the generic level.

This study was supported by National Research Council of Canada operating grants A-4688 (B.R.G.) and A-256I (Dr G. C. Hughes). We thank the individuals mentioned in Table I and Dr E. S. Beneke, Michigan State University, East Lansing, for providing cultures and information. We are grateful to Mrs O. Volkoff who examined two of our cultures for the presence of viruses, and also thank Dr U. Padmanabhan and Mr K. Petersen for technical assistance.

\section{REFERENCES}

BurTon, K. (1968). Determination of DNA concentration with diphenylamine. In Methods in Enzymology, vol. XIIB, pp. I63-I69. Edited by L. Grossman and K. Moldave. New York: Academic Press.

Clark-Walker, G. D. \& Gleason, F. H. (1973). Circular DNA from the water mold Saprolegnia. Archiv für Mikrobiologie 92, 209-216.

Dick, M. W. (1972). Morphology and taxonomy of the Oomycetes, with special reference to the Saprolegniaceae, Leptomitaceae and Pythiaceae. II. Cytogenetic systems. New Phytologist 7I, I I5I-I I59.

Drck, M. W. (1973). Saprolegniales. In The Fungi-An Advanced Treatise, vol. IVB, pp. I I3-I44. Edited by G. C. Ainsworth, F. K. Sparrow and A. S. Sussman. New York: Academic Press.

Dick, M. W. \& WiN-TIN (1973). The development of cytological theory in the Oomycetes. Biological Reviews 48, I33-I58.

Gibson, I. \& HEwITT, G. (1972). Interpopulation variation in the satellite DNA from grasshoppers with B-chromosomes. Chromosoma 38, I 2 I-138.

Green, B. R. \& Dick, M. W. (1972). DNA base composition and the taxonomy of the Oomycetes. Canadian Journal of Microbiology 18, 963-968.

Heath, I. B. \& Unestam, T. (I974). Mycoplasma-like structures in the aquatic fungus Aphanomyces astaci. Science, New York 183, 434-435.

Ingle, J., Pearson, G. G. \& Sinclair, J. (1973). Species distribution and properties of nuclear satellite DNA in higher plants. Nature, New Biology 242, 193-197.

MARMUR, J. (I96I). A procedure for the isolation of deoxyribonucleic acid from microorganisms. Journal of Molecular Biology 3, 208-218.

NeISH, G. A. (1975a). Carbenicillin as an aid in obtaining bacteria-free cultures of Saprolegnia species. Mycologia 67, I192-1 197.

NeISH, G. A. (1975 b). Observations on the growth and morphology of Emerson's Saprolegnia sp. 47-I5a. Canadian Journal of Botany 53, 1423-1427.

Schildkraut, C. L., Marmur, J. \& Doty, P. (1962). Determination of the base composition of deoxyribonucleic acid from its buoyant density in CsCl. Journal of Molecular Biology 4, 430-443.

SCUDDER, C. G. E. (1974). Species concepts and speciation. Canadian Journal of Zoology 52, I I 2 I-I I 34.

Seymour, R. (1970). The genus Saprolegnia. Nova Hedwigia 19, I-24.

StorCK, R. (1974). Molecular mycology. In Molecular Microbiology, pp. 423-477. New York: Wiley.

Storck, R. \& Alexopoulos, C. J. (I970). Deoxyribonucleic acid of fungi. Bacteriological Reviews 34, I26I54.

Volkoff, O., Walters, T. \& Dejardin, R. A. (1972). An examination of Penicillium notatum for the presence of Penicillium chrysogenum-type virus particles. Canadian Journal of Microbiology 18, I352-I 353.

WALKER, P. M. B. (I97I). Origin of satellite DNA. Nature, London 229, 306-308. 